\title{
Perceived challenges faced by the internal audit function in the South African public sector: A case study of The National Treasury
}

\author{
Nebbel Motubatse ${ }^{\mathrm{a}^{*}},{\text { Karin } \text { Barac }^{\mathrm{b}} \& \text { Elza Odendaal }}^{\mathrm{c}}$ \\ ${ }^{a}$ Faculty of Economics and Finance, Tshwane University of Technology, Pretoria, South Africa \\ ${ }^{\mathrm{b}}$ Department of Auditing, University of Pretoria, Pretoria, South Africa \\ ${ }^{c}$ Department of Auditing, University of South Africa, Pretoria, South Africa \\ *Corresponding author email: motubatsekn@tut.ac.za
}

\begin{abstract}
This article reports on the challenges faced by the internal audit function in the South African public sector, as perceived by role players other than the internal audit function itself. This study implemented a qualitative research design, using a case study as a research method, in order to achieve the research objective. Semi-structured interviews were conducted to obtain participants' perceptions of the challenges faced by the internal audit function. Participants were selected based on their capacity to act on the findings and recommendations of the study. Participants selected were senior managers, operational managers, and members of audit committees. The biggest challenges facing the internal audit were identified as the lack of business knowledge; lack of management support; lack of audit action monitoring processes, and external auditors' preference not to rely on the work of the internal audit function. Based on these findings, the authors make recommendations that could benefit the public sector internal audit functions by helping them to better understand the public sector environment and to identify areas for improvement. Finally, the article suggests avenues for further research on the future of the internal audit in the public sector.
\end{abstract}

Keywords: internal audit function, internal control, public sector, risk management, South Africa

\section{Introduction}

Auditing the public sector environment can be a complex experience, due to the many policies and legislative frameworks saturating the field. The internal audit function in the South African National Treasury is faced with numerous challenges. Those of relevance to this article include: internal auditors not understanding the core function of the public sector environment; external auditors not relying on the work of internal audits; a lack of management support; and a lack of audit action monitoring processes. Considered in the light of these challenges, the increasing scope of the public sector mandate becomes a fundamental concern. Owing to the nature of the role of the internal audit function, it does not necessarily have to understand everything about the business operations and environment in which it functions: with its technical knowledge and competencies it should still be able to make recommendations and offer advice on areas that may have an impact on the business' risk (PriceWaterhouseCoopers 2010). The internal audit function in the public sector should be able to learn about the business operations and environment by reviewing the organisational systems, risk assessments, and operational strategies (Alktani and Ghareeb 2014: 94; 
Diamond 2002; Getie Mihret, Ali, and Berhe 2014: 10341; Getie Mihret and Wondim Yismaw 2007; Van Gansberghe 2005). Essentially, internal audit functions need to prioritise the changing expectations and needs of the business environment (Frigo 2002) in order to respond appropriately. The purpose of this article is to identify challenges faced by the internal audit function in the public sector from the perspectives of senior managers, operational managers, external auditors, and audit committees. This is achieved by asking the participants the research question: 'What are the challenges faced by the internal audit function in your department?' The findings reported in this article indicate that the primary concerns raised by participants are that the internal audit function does not understand the business of the public sector environment, and that management does not support the activities of internal audit functions

\section{Regulation of the internal audit function in South Africa}

The importance of internal auditing in South African public sector organisations has been recognised in the Public Finance Management Act (PFMA) (RSA 1999, s 38(1) \& 76(4)), Treasury Regulation 3.2 (RSA 2005, para 3.2) and the Municipal Finance Management Act (MFMA) (RSA 2003, s 165), all of which are compatible with the Constitution (RSA 1996, s 216). The regulatory framework for the establishment of internal audit functions in the public service is also outlined in the internal audit framework of the public sector (RSA 2009), which provides the minimum guidelines for the development and operation of internal auditing in the public service. This framework provides guidance for internal audit functions in the public service, and is intended to ensure that internal audit functions comply with the requirements of the Constitution, the PFMA, the Treasury Regulations, the MFMA, the International Professional Practice Framework (IPPF), and the Committee of Sponsoring Organisations' (COSO) framework on internal control and risk management (RSA 2009). However, the King III Report (Institute Of Directors 2009) does not recommend a one-sizefits-all approach towards internal auditing, preferring that it remains flexible in order to accommodate the requirements of different organisations in their various operational environments. In other words, organisations should decide how to apply King III's principles of good governance in their own environments. The King III Report states that internal auditing plays an integral role in providing management with reasonable assurance about the effectiveness of the organisation's governance, risk management, and systems of internal control (Institute of Directors 2009). While the King II Report (Institute of Directors 2002) also supports the establishment of an internal audit function as one of the proponents of good governance for implementing checks and balances in the organisations, Coupland $(1993,4)$ views the role of internal audit functions in the public sector as providing independent appraisal and review services to determine and report on the degree of control exercised over financial systems.

\section{Literature review}

It is apparent from the previous section that the internal audit function in South Africa operates within an extensive legislative framework. In this section, the article reviews 
pertinent literature on the role of the internal audit function, and on the specific duties and responsibilities of internal audit in the public sector.

\section{Role of internal audit in the South African public sector}

Internal audit in the public sector plays its role as part of financial management (Barac and Van Staden 2014; Erasmus and Fourie 2014; Getie Mihret et al. 2014; Motubatse 2014; Plant 2014; Steyn 2014). The role of internal auditing makes provision for value-adding assurance and consulting services and for dealing with matters of efficiency and effectiveness, in addition to assessing the accuracy of recordings (Bou-Raad 2000; Getie Mihret et al. 2014). Getie Mihret and Wondim Yismaw (2007) argue that the essence of the contribution made by internal auditors remains the improvement of internal control systems and the provision of quality information to management for decision-making purposes. Yet, on the whole, the internal audit function in the South African public sector has not yet been the subjected to extensive research by scholars in accountancy related fields. The academic literature relevant to public sector internal audit could be described as "limited, but developing" (Barac and Van Staden 2014; Coetzee 2014; Erasmus and Fourie 2014; Motubatse 2014; Plant 2014; Steyn 2014). The relative paucity of prior research notwithstanding, there has been some interesting development elsewhere on the role of internal audit in the public sector, which has revealed that an internal audit does not impact the management control of the public sector as a critical challenge (Enofe et al. 2013). Within the scope of the literature review, the evaluation of the quality of work of internal audit in the public sector was also investigated in Saudi Arabia, which showed that lack of independence is still a challenge among internal auditors (Alktani and Ghareeb 2014).

In spite of the importance of the internal audit function in the public sector, Alktani and Ghareeb $(2014,103)$ point out other challenges facing internal audit in the public sector, which include "lack of training programme[s]; complexity of operation; constant changes in laws and regulations; non-cooperation of departments with internal audit; and constraints on the financial budget". In the South African public sector, Paragraph 3.2.11 of the Treasury Regulations (RSA 2005, paragraph 3.2) states that "the role of internal audit functions within public service institutions is to evaluate the effectiveness and efficiency of the institution's system of internal control and to make recommendations for the enhancement or improvement of that system. Internal audit functions in the public sector are also allowed to assess the effectiveness of the utilisation of public service institutions' resources and to provide the head of administration or the accounting officer with independent assurance of whether or not the resources are being used effectively, efficiently, and economically" (RSA 2005, paragraph 3).

From a public sector perspective, (here also referring to the Acts of Parliament, government instructions, policies and procedures) the importance of internal control is emphasised in the PFMA, the MFMA, the Treasury Regulations, and the King III Report. The roles of internal audit functions, as set out in Paragraph 3.2.11 of the Treasury Regulations (RSA 2005, paragraph 3.2), are based on the COSO framework on internal control (COSO 1992), which is intended for use in public service institutions. Pickett (2003) supports the adoption of the COSO framework on internal control in the public sector and recommends that the public sector organisations, including the National Treasury, should be responsible for setting standards relating to internal auditing and accountability across all facets of government. Analysis of the COSO framework on internal control by Rezaee (1995) indicates that the framework helps organisations to better understand the value and importance of a good internal control system, to identify elements and components that would expand internal control, and to provide guidelines for establishing criteria against which all organisations can 
assess the adequacy and effectiveness of their internal control systems. This serves to emphasise that the framework is fit for purpose.

The COSO framework on internal control was followed by the publication of Enterprise Risk Management (ERM) - Integrated Framework in 2004 (COSO 2004). Its objective was to offer organisations a commonly accepted model for evaluating risk management efforts. It expands on internal control concepts by providing a more robust focus, based on the broader subject of ERM (IIA 2012), thus providing direction and guidance for identifying, measuring, prioritising, and responding to risk (COSO 2004).

Hence, internal audit functions fulfil their role by functioning as control and risk educators and consultants (Chapman and Anderson 2002). This is accomplished by facilitating ERM workshops, coaching management in how best to respond to risks, coordinating ERM activities, consolidating reporting on risks, maintaining and developing the ERM framework, championing the establishment of ERM, and developing a risk management strategy for approval by the board of directors (COSO 2004).

According to Diamond (2002), consensus on the role of an internal audit function in both the private and public sectors appears to be that it helps an organisation to accomplish its objectives and evaluates and improves the effectiveness of the organisation's risk management, control and governance processes, as outlined in the COSO frameworks. In addition to providing support for senior management, internal audit functions in public service institutions also provide the organisations with acceptable recommendations on the organisations' internal control systems and risk management, using the COSO frameworks as guidelines.

In the South African public sector, the National Treasury regards the COSO frameworks on internal control and ERM as embodying international best practices, thus providing guidelines designed to improve public service institutions' performances on internal control, ERM and fraud deterrence (RSA 2009, 9). The COSO frameworks thus provide internal auditors with guidelines within which to assess public sector policies, rules and regulations.

\section{The duties and responsibilities of internal audit functions}

Diamond (2002) highlights the duties and responsibilities of internal audit functions in public sector organisations (within the relevant legislative frameworks) as being to provide services in the area of compliance with existing government regulations, instructions and procedures; to evaluate the effectiveness of internal control systems, and to appraise the economy and effectiveness with which financial and other resources are being used. Van Gansberghe (2005) agrees with some of the above-mentioned duties and responsibilities, and suggests that internal auditing in the public sector also includes administrative procedures, such as checking documents, counting assets, and reporting on past events to various audit clients (for example management). According to Stačiokas and Rupšys (2005) and Pickett (2003), internal audit functions are usually responsible for the following: assessing the safeguarding of assets; facilitating self-assessment; assessing business risks; evaluating governance processes; performing quality reviews; investigating fraud; evaluating internal controls; reviewing and assessing operating processes; reviewing accounting and financial information; ensuring compliance with laws, regulations and contracts, and assessing the efficient use of resources.

According to Coffin and Patilis (2001), internal auditing can significantly help to determine and evaluate the controls surrounding the collection, use of, and access to client information, as well as compliance with applicable regulations. Government internal auditors furthermore advise elected officials and top administrative management, such as directors general and audit committees, on how tax-generated resources are being used (Malan 1991). It is evident 
that both management and audit committees are concerned about the proper functioning of an organisation's internal controls, ethics, governance, and risk management processes.

Stačiokas and Rupšys (2005) further state that internal audit functions are responsible for recommending to senior management how processes in an organisation can be improved. Sawyer, Dittenhofer, and Scheiner (2003) agree, and further claim that internal audit functions assist members of the executive and senior management in the effective discharge of their duties and responsibilities.

According to Dittenhofer (2001), an internal audit function should be active in trying to determine what it can do to help its clients and should anticipate client needs. Stačiokas and Rupšys (2005) explain that an internal audit function may potentially experience conflicts of interest when serving its clients. Senior management may, for example, be interested in activities directly affecting the bottom line in the profit and loss accounts, and thus their bonuses, to the detriment of "the general good" of the society that that government entity is set up to serve.

Given the aforementioned roles of internal audit functions in the public sector, PriceWaterhouseCoopers (2010) conclude that internal audit functions in the public sector should assist management with the following: regulatory compliance; the assessment of current and future regulatory risk profiles and the impact of regulations; effectiveness reviews of current compliance with policies; the implementation of risk-based compliance control frameworks and monitoring programmes; the evaluation of the impact of new regulations on the business model; giving advice on and assistance with regulatory relations, and ensuring that regulatory standards and expectations are met.

\section{Methodology}

The aim of this article is to identify the challenges faced by the internal audit function in the National Treasury, using a case study research design and method. A case study is an indepth examination of a single instance of a social phenomenon (Babbie 2013). According to Yin (2011) a phenomenon has to be based on the real world context. Since the case study only involves the National Treasury, this article adopts a descriptive qualitative approach using participants' views of the challenges faced by the internal audit function in the National Treasury. The research design consists primarily of a case study of the South African National Treasury, which was used in order to describe the perceived challenges faced by the internal audit function in the South African public sector. The participants were senior managers (deputy directors general) and operating managers (chief directors and directors). The National Treasury was chosen for this case study because it plays a critical role as custodian of the policy guidelines and operational frameworks that guide the internal audit function's performance in the broader South African public sector.

The case study follows a qualitative approach in order to gain insight into the participants' behaviour towards and concerns about the challenges faced by the internal audit function. Owing to the nature of this research question, semi-structured interviews were used to gain a clear understanding of the participants' beliefs about and perceptions of the challenges facing the internal audit function. The researchers chose to perform interviews because this method of gathering data is suitable for use when working with a small sample and when looking for specific information (Rubin and Rubin 1995). Thus, semi-structured interviews were used as the research instrument, because, as De Vos et al. (2005) maintain, semi-structured interviews provide a detailed picture of a participant's beliefs about a particular phenomenon. 


\section{Participants}

Senior managers, operating managers, external auditors, and the audit committee participated in the study. The inclusion criteria for the participants were: senior managers (deputy directors general) and operating managers (chief directors) who have authority to implement the internal audit function's recommendations. One member of the audit committee, the chairperson, participated as representative of the views of the members while the views of an external auditor responsible for the audit of National Treasury were also considered. For convenience, all participants were interviewed at their places of work. Table 1 below indicates the category and number of participants involved in the study.

Table 1: Category and number of participants

\begin{tabular}{lc}
\hline Category of participants & Number of participants \\
\hline Member of the audit committee & 1 \\
Senior managers & 3 \\
Operating managers & 3 \\
External auditor & 1 \\
Total number of participants & 8 \\
\hline
\end{tabular}

\section{Data collection}

Qualitative data was collected by means of interviews designed to require the participants to answer the research question (Kumar 2011). Eight participants were interviewed. The question 'What are the challenges faced by the internal audit function in your department?' was used to initiate and focus the data gathering process. This was done in order to gain a better understanding of the perceptions of the senior managers, operating managers, external auditors, and the audit committee of the challenges faced by the internal audit function in the National Treasury. Data were collected from primary sources, through the use of semistructured interviews.

\section{Ethical considerations}

According to Aluwihare-Samaranayake $(2012,76)$ 'qualitative research is used as a means to explore and capture persons' subjective experiences, meanings, and voices and can result in ethical challenges for participants and the researchers'. Qualitative inquiry requires ethical consideration (Creswell 2013). The ethical considerations for qualitative research were taken into account in preparing this article. Important ethical requirements regarding the informed consent of the participants and assurances of confidentiality were followed. Permission to conduct the research was obtained from the National Treasury in 2011. The research also obtained signed consent letters from the participants as an assurance that their participation was voluntary and that the participants were aware they could withdraw at any time.

\section{Data analysis}

The semi-structured interviews were analysed by means of coding the collected data to allow the identification of themes and subthemes. Coding in qualitative research consists of the assignment of short phrases to capture a meaning of a large portion of textual data (Yin 
2011). Babbie $(2013,550)$ and Saldaña $(2009,8)$ both define 'coding' as a process of arranging raw data into a standardised form. The process began with a review of recordings and transcripts of the interviews. While considering the whole context, the data was coded. The coded data facilitated the comparison of the different views held by the participants, which were then built into the themes.

\section{Results and discussion}

Considering the profound importance of the internal audit function in the South African public sector (Barac and Van Staden 2014; Coetzee 2014; Erasmus and Fourie 2014; Motubatse 2014; Plant 2014; Steyn 2014; Van Gansberghe 2005), it is worth identifying and appreciating the challenges facing the internal audit function in the public sector, and of understanding the complexity of the public sector environment in South Africa. This section of the article presents the results and a discussion of the findings arising from the semistructured interviews in relation to the research objective. The semi-structured interviews were analysed using a descriptive research approach. The participants were categorised as directors general, deputy directors general, chief directors, external auditors and audit committee members. The internal audit function's lack of knowledge of the business operations (the environment in which it operates) and the general lack of management support, lack of audit action monitoring, and the fact that external auditors do not rely on the work of internal audit were perceived to be significant challenges by the participants. The results are presented in the form of theme and subthemes (see Table 2).

Table 2: Theme and subthemes

\begin{tabular}{ll}
\hline Theme & Subthemes \\
\hline $\begin{array}{l}\text { Challenges faced by the } \\
\text { internal audit }\end{array}$ & Lack of business knowledge \\
& Lack of management support \\
& Lack of audit action monitoring \\
processes \\
External auditors not relying on the \\
work of internal audit
\end{tabular}

\section{Knowledge of the business}

The following responses summarise the sentiments expressed by participants in both the senior manager and operating manager groups about the challenges facing the internal audit: "Not understanding. You see they still [have] the attitude "we have got to find something wrong". So they ask us "what are the risks?" and then they write it down as if it were their findings."

"Then ... I find auditors sometimes shying away from just "okay I don't understand your system; I don't understand the process that you are following" ... then in some cases where you give them a response to say "this is done this way" and they don't understand the links between whatever it may be, policies or legislation, then they would insist on saying "no, we don't think this is working properly" or "this is not an appropriate answer" that we are giving." 
"Yes I think that is actually what we find [not] only in Treasury but [when] I have to talk generally. That is why internal auditor [get] the resistance [it] is because they go there, they understand the technique and what they need to do but your lack of understanding [of] the business becomes your challenge ... to a very large extent. No, no, actually that is the biggest; the number one biggest challenge of internal auditors is if you get audited by somebody who does not understand your environment you don't get value for money."

"They understand the environment. I think it is something which is, what can I say, it is not something which you can say a conclusive understanding, just general, a general understanding."

"... to answer your question directly, even taking into account my division, sometimes I don't understand how my division operates, what to necessarily look for, etc. If I take that and I superimpose it over the entire organisation then I will safely say I do not think sometimes they have got a fair understanding of what the department is all about ... but you can see it in the ... way in which the auditor audits."

An analysis of the above quotations indicates that the participants perceive the internal audit's lack of knowledge of the business operations and the environment in which the business operates as a significant challenge. However, owing to the nature of the role of the internal audit function in the public sector, the internal audit function should prepare for the challenges and begin to communicate with the people involved in the processes to be audited. The best possible approach available to the internal audit function may be to approach the people involved in these processes, in order to understand and obtain knowledge about the client's business environment. The internal audit function should be able to learn about the business operations and environment by reviewing the organisational systems, risk assessment and strategies.

\section{Lack of management support}

The sentiments shared by the member of the audit committee are encapsulated in the following quotations:

"Internal audit function is not as effective as we want it to be mainly because senior management [doesn't] give the internal audit the necessary support and respect. Respect [in] that they have lots of repeat findings and [those issues] are not [resolved]."

"So I think it's important if you put it in perspective ... that if we did not have this problem, [this] lack of support, I think the internal audit here ... could be very powerful."

The perceived lack of management support for the internal audit function could have negative effects on the operational effectiveness of and the value added by the internal audit function. Since it does not appear to receive sufficient support from management to be fully effective, the internal audit function does not have adequate standing in the public sector. Based on the empirical data collected in this study, it would appear that the audit committee participant is concerned about management's repeated discussions and slow implementation of the internal audit function's recommendations.

\section{Lack of audit action monitoring processes}

The audit committee participant views audit action monitoring processes as a remedial exercise to ensure that corrective action is taken on issues identified by the external auditors and internal auditors. The audit committee had the following to say in this regard:

"How long has it taken to resolve some of these issues? Then we can monitor it and say "how come you have an issue that is sitting here for two hundred and four days?" and it's something simple as writing up a policy on XYZ, so what is so difficult about that? That has 
been a challenge in management sometimes, resolving those things. So you have things sitting there for long [periods] because they haven't been addressed by management." In order to monitor the implementation of audit findings and recommendations, the audit committee requires the internal audit to compile a formal findings register that would indicate corrective actions taken and list the unresolved findings. This could also assist the audit committee in overseeing how management is responding to the recommendations made by external and internal auditors. It may also assist the audit committee to affect accountability and to follow up on critical audit recommendations.

\section{External auditors not relying on the work of the internal audit}

External auditors indicated that under certain circumstances they would rely on the work of the internal audit function, but that there were complicating factors:

“... for us to use their work is a bit tricky because their samples aren't as big as what we use to get an opinion ... if we have to rely on their work more, then obviously they have to increase their samples; we have to communicate on sample sizes and what is appropriate for us."

"For us to rely on the work of internal audit, we are looking at the period when ... they [did] the task and also the sample that they have selected: is [it] for which period. [...] we cannot rely on the work that was performed on the first two months, or the first three months ..." The above observations explain why the external auditor is reluctant to rely on the work of the National Treasury's internal audit function. It appears that the scope of the internal audit function's work is sometimes not broad enough to be of use to the external auditors. International Standard on Auditing 610 (2013/2014) requires external auditors to consider the nature and scope of specific work performed by the internal audit function in determining the extent to which external auditors will use the work of internal auditors. SAICA (2013/2014, ISA 610 paragraph A6) further determines that the nature, timing and extent of the audit procedures performed on specific work of the internal audit function will depend on the external auditor's assessment of the risk of material misstatement and their evaluation of the internal audit function's procedures. This may include the following: examining items that have already been examined by the internal audit function; examining other similar items, and observing the procedures performed by the internal audit function. The external auditor participant further stated that:

"We look also at the timing, the nature and also the extent of the procedures being performed by the internal auditors. So now we do the holistic review of the internal audit."

The manner in which the necessary coordination between the internal auditors and the external auditors is effected and communicated will influence the efficiency of the external audit. In the context of the scope of the internal audit function, Standard 2100 (Institute of Internal Auditors 2012) states that the internal auditor should evaluate and contribute to the improvement of risk management and control and governance systems. This indicates that the internal audit functions are concerned with the business operations of the organisation.

The findings from the above indicate that the external auditor participant has concerns about placing reliance on the work of the National Treasury internal audit function. It is evident that the external auditor participant also views the internal audit function as a management tool, the primary task of which is to assist management in all areas of the organisation by making comments and recommendations on risk, control, and governance. 


\section{Conclusion and recommendations}

This article reported on the perceived challenges facing an internal audit function in the South African public sector, as identified by role players other than the internal audit function itself. Challenges faced by the National Treasury's internal audit function were identified as the lack of business knowledge, a lack of management support, the lack of an audit action monitoring processes, and the external auditor's reluctance to rely on the work of internal audit. Research for this article was undertaken with a specific focus on identifying the views of senior managers, operating managers, external auditors, and the audit committee regarding their perceptions of the challenges faced by the internal audit function in the National Treasury. The research indicates that the internal audit function, as currently structured, does have a role to play within legislative frameworks and professional best practices. However, the literature review indicates that the internal audit function remains a key component of governance for providing valuable guidance on issues relating to control and risk in the public sector. Interviewees' views show less than enthusiastic endorsement of the internal audit function's output and effectiveness; hence, the impact of this article is in its recommendations.

Senior and operating managers should be made aware of the internal audit function's predicament relating to their role and their lack of specific operational knowledge. These managers should be encouraged to play an active role in empowering internal audit function staff by sharing their knowledge of public sector organisations' operations during their encounters. As a starting point, it is recommended that all staff in the internal audit function should understand the public sector and government's strategy and their related risks. The internal audit function should then align its work or plans to focus on the key aspects of the government mandate of service delivery. Such an alignment would help the internal audit function to understand the vision, mission, and strategies implicit in the public sector environment. By following the government service delivery mandate, the internal audit function would be able to obtain a holistic view of the business operations and environment of the public sector, and the risks related to government strategy, operations, financial and compliance risks. These recommendations would enable the internal audit function to develop an audit plan that would prioritise effective service delivery.

Based on the perceptions of the audit committee participant, senior managers should set the tone required to increase the standing of the internal audit function in the public sector. The internal audit function's standing could be improved by involving them at the strategic level and by seriously and effectively considering their recommendations. Such conduct could prevent management sending out the wrong signal to the rest of the public sector that currently appears to diminish the importance of the internal audit function. In the light of the finding regarding the lack of audit action monitoring processes, it is recommended that formal audit action monitoring processes should be introduced in the National Treasury, which will require management to commit themselves to respond swiftly to internal audit's recommendations.

As this article reported that the external auditors do not rely on the work of internal audit, it is important that both internal auditors and external auditors enter into open dialogue. The intention should be to identify shortcomings that prevent reliance being placed on the work of the internal audit function, and to discuss steps that could be taken to remove the impediments. An action plan in line with the requirements of Standard 2050, Coordination (Institute of Internal Auditors 2012) should be formulated. Standard 2050, Coordination (Institute of Internal Auditors 2012) expects the head of internal audits to share information and coordinate activities with other internal and external providers of assurance and 
consulting services to ensure proper audit and assurance coverage and to minimise duplicated efforts (Institute of Internal Auditors 2012).

\section{Acknowledgements}

The authors of this article wish to thank the Office of the Accountant General of the South African National Treasury for allowing this research study to take place, and to all participants for having participated in this study. Thanks are also given to anonymous referees for their valuable comments on an earlier version of this article.

\section{References}

Alktani, S., and A. Ghareeb. 2014. "Evaluation of the quality of the internal auditing position in the public sector in Saudi Arabia: An applied study." Global Review of Accounting and Finance 5 (1): 93-106.

Aluwihare-Samaranayake, D. 2012. "Ethics in qualitative research: A view of the participants' and researchers' world from a critical standpoint." International Journal of Qualitative Methods 11 (2): 64-81.

Babbie, E. 2013. The practice of social research. 13th ed. Belmont, CA: Wadsworth Cengage Learning.

Barac, K., and M. van Staden. 2014. "Internal auditing as a corporate governance mechanism: A comparison between public sector and private sector functions." African Journal of Public Affairs 7 (3): $17-31$.

Bou-Raad, G. 2000. "Internal auditors and value added approach on the new business regime." Managerial Auditing Journal 15 (4): 182-87. doi:10.1108/02686900010322461.

Chapman, C., and U. Anderson. 2002. Implementing the Professional Practices Framework. Altamonte Springs, FL: Institute of Internal Auditors.

Coetzee, P. 2014. "Stakeholders' view on the contribution of public sector internal auditing to enterprise risk management." African Journal of Public Affairs 7 (3): 48-59

Coffin, R. G., and C. Patilis. 2001. "The internal auditor's role in privacy.” Internal Auditor 16 (2): 22-28. http://elibrary.ru/item.asp?id=6044972

Committee of Sponsoring Organisations of the Treadway Commission. 1992. Internal control: Integrated framework. American Institute of Certified Public Accountants, New York. http://www.coso.org/ic.htm

Committee of Sponsoring Organisations of the Treadway Commission. 2004. Enterprise risk management (COSO ERM). Altamonte Springs, FL: Institute of Internal Auditors. http://www.coso.org/erm-integratedframework.htm

Coupland, D. 1993. "The internal auditor's role in public service orientation." Managerial Auditing Journal 8 (1): 3-13. doi:10.1108/02686909310023506.

Creswell, J. W. 2013. Qualitative inquiry and research design. 3rd ed. London: Sage. 
De Vos, A. S., H. Strydom, C. B. Fouché, and C. S. L. Delport. 2005. Research at grass roots for the social sciences and human service professions. 3rd ed. Pretoria: Van Schaik.

Diamond, J. 2002. The role of internal audit in government financial management: an international perspective. International Monetary Fund Working Paper/02/94.

Dittenhofer, M. 2001. "Reengineering the internal auditing organisation." Managerial Auditing Journal 16 (8): 458-68. doi:10.1108/02686900110403163.

Enofe, A. O., C. J. Mgbame, V. E. Osa-Erhabor, and A. J. Ehiorobo. 2013. "The role of internal audit in effective management in public sector." Research Journal of Finance and Accounting 4 (6): 16268. http://iiste.org/Journals/index.php/RJFA/article/view/5660

Erasmus, L. J., and H. Fourie. 2014. "Perceptions on internal audit function contributions in South African national government departments.” African Journal of Public Affairs 7 (3): 1-16.

Frigo, M. L. 2002. A balanced scorecard framework for internal auditing departments. Institute of Internal Auditors Research Foundation. Altamonte Springs, FL: Institute of Internal Auditors.

Institute of Directors. 2002. King report on corporate governance for South Africa. Johannesburg: Institute of Directors.

http://www.iodsa.co.za/PRODUCTSSERVICES/KingReportonGovernanceinSA/KingII.aspx

Institute of Directors. 2009. King report on corporate governance for South Africa. Johannesburg: Institute of Directors. [Online]. http://www.iodsa.co.za/PRODUCTSSERVICES/KingReportonGovernanceinSA/KingIII.aspx [Accessed 30 April 2014].

Institute of Internal Auditors. 2012. The International Professional Practice Framework (IPPF). Altamonte Springs, FL: Institute of Internal Auditors. https://na.theiia.org/standardsguidance/Pages/Standards-and-Guidance-IPPF.aspx

Kumar, R. 2011. Research methodology: A step-by-step guide for beginners. 3rd ed. London: Sage.

Malan, R. M. 1991. “Internal auditing in government.” Internal Auditor 48 (3): 90-95.

Getie Mihret, D., M. S. Ali, and A. G. Berhe. 2014. "The role of internal audit in public financial management: An Ethiopian public sector case study." International Journal of Current Research 6 (11): 10341-43.

Getie Mihret, D., and A. Wondim Yismaw. 2007. "Internal audit effectiveness: An Ethiopian public sector case study." Managerial Auditing Journal 22 (5): 470-84. doi:10.1108/02686900710750757.

Motubatse, K. N. 2014. "Perceived role of internal auditing in fraud prevention and detection in South African public sector national departments.” African Journal of Public Affairs 7 (3): 61-72.

Pickett, K. H. S. 2003. The internal auditing handbook. 2nd ed. Chichester, UK: Wiley.

Plant, K. 2014. "Internal audit outsourcing practices in the South African public sector." African Journal of Public Affairs 7 (3): 73-87.

PriceWaterhouseCoopers. 2010. Audit and assurance services. Global: PricewaterhouseCoopers International Limited. http://www.pwc.com/gx/en/about-pwc/index.jhtml 
Republic of South Africa National Treasury. 2009. Internal Audit Framework (2 $2^{\text {nd }}$ ed), Pretoria: National Treasury.

Republic of South Africa. 2005. 1996. The Constitution of the Republic of South Africa as updated, including the Constitution Twelfth Amendment Act. Pretoria: Government Printer.

Republic of South Africa. 1999. Public Finance Management Act 1 of 1999. Government Gazette, 19814:28 and 56, 2 March. Pretoria: Government Printer.

Republic of South Africa. 2003. Municipal Finance Management Act 56 of 2003. Government Gazette, 26019:152, 13 February. Pretoria: Government Printer.

Republic of South Africa. 2005. Public Finance Management Act 1999: Amendment of Treasury Regulations in terms of Section 76 as set out in the Schedule. Regulation Gazette, 27388:9-10, 15 March. (Regulation Gazette No. 8189.)

Rezaee, Z. 1995. "What the COSO report means for internal auditors." Managerial Auditing Journal 10 (6): 5-9. doi:10.1108/02686909510088350.

Rubin, H. J., and I. S. Rubin. 1995. Qualitative interviewing: the Art of hearing data. Thousand Oaks, CA: Sage.

South African Institute of Chartered Accountants. 2013/2014. ISA 610: Using the work of internal auditors, SAICA Handbook, 2(a). Durban: LexisNexis.

Saldaña, J. 2009. The coding manual for qualitative researchers. London: Sage.

Sawyer, L. B., M. A. Dittenhofer, and J. H. Scheiner. 2003. The practice of modern internal auditing. 5th ed. Altamonte Springs, FL: Institute of Internal Auditors.

Stačiokas, R., and R. Rupšys. 2005. "Application of internal audit in enterprise risk management." Engineering Economics 42 (2): 20-25.

Steyn, B. 2014. "Heading up internal auditing in the public sector: Profiling the chief audit executives (CAEs) of South African national government departments." African Journal of Public Affairs 7 (3): $88-102$.

Van Gansberghe, C. N. 2005. Internal audit: Finding its place in public finance management. Washington, DC: International Bank for Reconstruction and Development/The World Bank. http://siteresources.worldbank.org/WBI/Resources/Internalaudit.pdf.

Yin, R. K. 2011. Qualitative research from start to finish. New York: The Guilford Press. 